\title{
Penerapan Hybrid Contract sebagai Inovasi pada Produk Pembiayaan Multijasa di Lembaga Keuangan Syariah
}

\author{
${ }^{1 *}$ Neni Hardiati, ${ }^{2}$ Yoyok Prasetyo, ${ }^{3}$ Nana Herdiana Abdurrahman \\ ${ }^{1-3}$ Program Studi magister Hukum Ekonomi Syariah, Pascasarjana UIN Sunan Gunung Djati \\ Bandung
}

Article history

Received: 10 Oktober 2021

Revised: 20 Oktober 2021

Accepted: 20 November 2021

*Corresponding Author:

Neni Hardiati

Program Studi magister Hukum Ekonomi Syariah, Pascasarjana UIN Sunan Gunung Djati Bandung

Email:

nenihardiati@gmail.com

\begin{abstract}
Rapid product development is carried out by Islamic Financial Institutions (LKS) in providing alternative services to the needs of the community which are carried out based on sharia principles. The development of these services is provided both in the form of banks and non-banks as well as in the form of storage or other types of services as well as in the form of financing. However, due to more complex customer needs, LKS requires innovation in order to get convenience in its operational activities. So, in innovating with hybrid contracts, it becomes an important thing. This research uses a literature study with a normative juridical approach, which is carried out by collecting, studying and reviewing books, scientific magazines and documents related to this research such as theses and scientific articles. The results of the study state that in the application of hybrid contracts in multi-service financing products at Islamic Financial Institutions (LKS) generally use ijarah contracts according to the DSN-MUI fatwa. In this case, if the LKS uses the ijarah contract, it must comply with the provisions of the fatwa as the service provider or the benefits obtained from the LKS. Meanwhile, if in a hybrid contract one or more contracts are added, in this case it is added with a wakalah contract, then the customer has the power to carry out his own costs. However, if there are customers who still have to pay ujrah for the ijarah contract, it is called usury. Because this is not justified in sharia principles and is not in accordance with the ijarah fatwa concerning the multiservice, the bank does not fulfill its service obligations as the fatwa regarding multiservice as well as the kafalah contract. Thus, there is an alternative in this multi-service financing, namely by using hawalah bil ujrah and wakalah contracts which are more flexible and their implementation as an innovation, namely combining these contracts with the aim of making banking operations easier, reaching wider and able to meet the needs of more customers.
\end{abstract}

Keywords: Hybrid Contract, Financing, Multiservice Products, Islamic Financial Institutions (LKS)

\section{PENDAHULUAN}

Berkembangnya Lembaga keuangan syariah menjadi suatu alternatif dalam memenuhi kebutuhan masyarakat yang semakin kompetitif, sehingga produk pembiayan bank syariah membuat produk baru yakni dengan adanya produk pembiayaan multijasa. Objek dari multijasa ialah jasa itu sendiri. Baik berupa manfaat atas barang ataupun atas jasa/tenaga kerja. Pada pemberian multijasa ini bank memperoleh imbalan atau fee (ujrah) berdasarkan kesepakatan diawal dengan nominal bukan presentase. Sehingga LKS untuk memperoleh kemudahan pada operasionalnya tanpa mengurangi keuntungan yakni dengan 
mengurangi biaya tenaga kerja pada pemberian jasa terhadap nasabah. Sehingga dibutuhkan desain akad yang tidak tunggal namun menggabungkan beberapa akad yang dikenal dengan istilah multi akad (Indonesia), al-uqud al-murakkabah (Arab) dan hybrid contract (Inggris) (Riyaldi \& Choirunnisak, 2021).

Multi akad (hybrid contract) menjadi suatu hal penting dalam menciptakan produk keuangan syariah untuk mencukupi keperluan dalam masyarakat modern. Namun ada persoalan yakni literature yang telah lama ada memberikan teori bahwasanya tidak memperbolehkan dua akad dalam satu transaksi sehingga menyempitkan dalam mengembangkan produk bank syariah. Padahal lingkup syariah itu luas. Menggabungkan dua akad maupun lebih pada kesepakatan transaksi sudah lazim dipakai pada bank syariah. Pada setiap transaksi suatu produk tidak bisa ditinggalkan sehingga akad-akad tersebut dilaksanakan dengan bersamaan (Nugraheni, 2015).

\section{METODE PENELITIAN}

Pada penelitian ini mengguankan pendekatan yuridis normatif yang didasarkan pada bahan hukum utama dengan mempelajari teori, konsep, dan prinsip hukum peraturan perundang-undangan yang berkaitan dengan penelitian ini (Hakim \& Mubarok, 2017). Jenis penelitian yang digunakan adalah kualitatif yaitu penelitian yang bersifat deskriptif dan cenderung menggunakan analisis. Sedangkan metode yang digunakan adalah metode penelitian analisis deskriptif, namun merupakan metode mendeskripsikan atau meringkas objek penelitian melalui data dan sampel yang dikumpulkan sebagaimana adanya (Sugiyono, 2017). Pengumpulan data penulis menggunakan studi pustaka dari artikel dan karya ilmiah (seperti buku, jurnal, dan artikel ilmiah lainnya) mengandung pokok-pokok yang dapat digunakan dalam menelaah penerapan hybrid contact pada produk pembiayaan multijasa di Lembaga Keuangan Syariah (LKS).

\section{HASIL DAN PEMBAHASAN}

\section{A. Hybrid Contract}

Hybrid contract atau dalam bahasa Indonesianya multi akad. Sementara kata multi dalam bahasa Indonesia memiliki arti banyak, lebih dari satu, lebih dari dua, serta berlipat ganda. Oleh sebab itu, makna dari multi akad yakni akad berganda ataupun akad yang banyak, serta akad yang di dalamnya terdapat lebih dari satu akad. Namun, dalam istilah fikih, kata multi akad merupakan terjemahan dari bahasa Arab yakni al-uqud almurakkabah yang berarti akad ganda. Al- uqud al-murakkabah terdiri dari dua kata al-uqud wujud jamak dari aqd serta al-murakkabah. Kata aqd yang berarti perjanjian. Sementara kata Al-murakkabah (murakkab) secara etimologi berarti al-jamu, yakni mengumpulkan serta menghimpun (Mumtahaen, n.d.).

Kata murakkab sendiri berasal dari kata "rakkaba-yurakkibu-tarkiban" yang mempunyai arti menentukan sesuatu terhadap sesuatu yang lain. Sehingga menjadi menumpuk, ada yang di atas serta yang di bawah. Sementara murakkab menurut para ulama fikih yakni:(Maulana, 2020)

a. Kumpulan berbagai hal sehingga disebut dengan sebuah nama. Seseorang menjadikan berbagai hal menjadi satu hal (satu nama) disebut dengan melaksanakan perkumpulan.

b. Sesuatu yang dibuat dari dua maupun berbagai bagian, sebagai kebalikan dari sesuatu yang sederhana atau tunggal yang tidak mempunyai bagian-bagian,

c. Meletakkan sesuatu di atas sesuatu lain serta menghimpun sesuatu dengan yang lainnya. Sehingga Hybrid contract yang ada pada transaksi LKS mempunyai 
banyak bentuk serta ragamnya. Secara umum, hybrid contract ini terbagi ke dalam berbagai bentuk sebagai berikut:

a. Hybrid contract dalam bentuk percampuran dua akad maupun lebih yang memunculkan nama baru. Hybrid contract ini misalnya jual beli tawarruq, serta lain sebagainya. Jual beli tawarruq ialah percampuran dua akad jual beli, jual beli dengan pihak pertama serta jual beli dengan pihak ketiga.

b. Hybrid contract yang mujtami'ah yakni dengan nama akad baru, tetapi menyebut nama akad yang lama sebagai basis. Hybrid contract ini misalnya mudhrabah musytarakah pada asuransi jiwa serta deposito bank syariah, dan produk musyarakah mutanaqishah

c. Hybrid contract yang ketiga yakni, akad-akadnya tidak bercampur serta tidak melahirkan nama akad baru, tetapi dua akad ataupun lebih itu menjadi satu paket kesepakatan dengan nama akad dasarnya tetap ada. Hybrid contract ini contohnya ialah murabahah wal wakalah terhadap pembiayaan murabahah di perbankan syari'ah; kafalah bil ijarah pada kartu kredit, letter of credit, bank garansi, pembiayaan multi jasa, serta kartu kredit; qardl, rahn, serta ijarah pada produk gadai dan sebagainya (Nurcholis Syamsudin, 2019).

\section{B. Multijasa}

\section{Pengertian Pembiayaan Multijasa}

Pembiayaan multijasa dapat dimaknai yakni sebagai pembiayaan yang diberikan oleh Lembaga Keuangan Syariah (LKS) kepada nasabah dalam memperoleh manfaat serta jasa. Misalnya pada transaksi ijarah dalam pembiayaan multijasa yakni transaksi sewamenyewa atas sebuah barang maupun jasa antara yang memiliki modal obyek sewa, termasuk kepemilikan hak pakai atas obyek sewa dengan penyewa, agar memperoleh imbalan atas obyek sewa yang di sewakan. Sementara multijasa terdiri dari dua kata yakni multi yang memiliki makna banyak, beraneka serta kata jasa yang bermakna perbuatan yang bermanfaaat atau nilai tinggi terhadap orang lain. Sehingga multijasa merupakan sebuah perbuatan manfaat yang bermacam-macam manfaat yang bermanfaat terhadap orang lain (Asfiyah, 2015).

Pembiayaan multijasa yang sering dilakukan oleh LKS selama ini yakni pembiayaan multijasa yang menggunakan dasar dari akad ijarah atau kafalah sesuai dalam fatwa Dewan Syariah Nasional (DSN) MUI no. 44/DSN-MUI/ VII/2004 mengenai pembiayaan multijasa. Dalam fatwa DSN tersebut secara umum memperbolehkan pembiayaan multijasa asal dengan ketentuan fatwa DSN-MUI No.44/DSN-MUI/VII/2004 ketentuannya Multijasa, yakni:

a. Pembiayaan multijasa hukumnya jaiz (boleh) dengan memakai akad ijarah atau kafalah.

b. Jika LKS memakai akad ijarah maka wajib mengikuti seluruh ketentuan yang ada pada fatwa ijarah tersebut.

c. Jika LKS menggunakan akad kafalah, maka wajib tunduk pada fatwa kafalah.

d. Dari kedua akad pembiayaan multijasa tersebut, LKS dapat memperoleh imbalan jasa fee atau ujrah.

e. Ketentuan besaran ujrah atau fee wajib disepakati di awal dan dinyatakan dalam nominal bukan pada bentuk presentase.

Akan tetapi dalam pembiayaan multijasa baik dengan akad ijarah atau dengan akad kafalah, tidak bisa diterapkan begitu saja dalam seluruh keperluan nasabah. Hal ini dikarenakan jika produk multijasa tersebut berlandaskan pada akad ijarah, maka multijasa tersebut terikat dengan seluruh ketentuan akad ijarah, baik dalam rukun, syarat, ataupun ketentuan lainnya, sebagaimana yang telah dikukuhkan pada fatwa DSN MUI mengenai 
pembiayaan multijasa. Pada fatwa DSN MUI nomor 09/DSN-MUI/ /IV/2000 mengenai pembiayaan akad Ijarah dinyatakan bhawasanya objek dari akad ijarah yaitu manfaat barang serta sewa maupun manfaat jasa serta upah. Fatwa tersebut juga menyatakan bahwasanya bagian dari ketentuannya yakni objek ijarah merupakan kegunaan dari penggunaan barang serta atau jasa serta kegunaan barang maupun jasa tersebut wajib bisa dinilai serta bisa dilakukan dalam akad (Rahayu, 2020)

Sementara para fuqaha dalam mendefinisikan ijarah bebeda-beda, akan tetapi secara general subtansinya sama. Secara sederhana ialah yang dinukil oleh 'Aishah al-Sharqawi, yakni jual beli manfaat suatu tertentu dengan harga atau pengganti tertentu. Ijarah dalam pemahaman fuqaha dispesifikasikan pada dua kelompok, yakni kelompok sewa-menyewa serta kelompok dalam hal upah-mengupah. Kedua makna tersebut dalam terminologi fikih mempunyai kesamaan memakai istilah ijarah.

Sehingga dalam akad Ijarah merupakan pengertian dari sewa-menyewa maknai sebagai akad pemindahan hak manfaat atas barang dengan pembayaran upah sewa tanpa diikuti dengan pemindahan kepemilikan atas barang tersebut. Akad ijarah dipakai untuk objek transaksi seperti barang yang tidak habis digunakan maupun barang yang jika sudah habis masa sewanya bisa dikembalikan terhadap pemiliknya misalnya rumah, gedung, kantor, ruko, kendaraan, hewan dan sebagainya. Dalam hal ini, LKS memiliki fungsi sebagai pihak yang menyewakan (mu'ajjir) serta nasabah sebagai pihak yang menyewa (musta'jir).

Berdasarkan ketentuan-ketentuan tersebut, pembiayaan multijasa jika memakai akad ijarah dalam definisi sewa-menyewa rumit untuk terapkan. Sebab hal ini, LKS tidak memiliki aset/barang yang bisa disewakan kepada nasabah sehingga LKS tidak bisa secara langsung menyewakan barangnya kepada nasabah, namun LKS wajib mempunyai barang tersebut terlebih dahulu melalui akad sewa maupun jual beli. Ditambah lagi biasanya nasabah ingin mencari sendiri barang yang akan disewa. Sebab itu, alternatif dalam pembiayaan ini ialah dengan memakai ijarah paralel. Ijarah paralel memiliki pengertian yakni melakukan dua transaksi ijarah (sewa) antara bank serta pihak ketiga, juga diantara bank dengan nasabah secara simultan. Hal ini mirip dengan salam paralel yang sudah dikenal dalam perbankan syariah.

Sementara akad Ijarah dalam makna upah-mengupah dipakai agar objek pekerjaan maupun jasa yakni akad dalam melaksankan pekerjaan tertentu dengan pembayaran upah, misalkan upah pekerja rumahan, buruh pabrik, tukang kebun, karyawan diperusahaan dan lain sebagainya. Dalam hal ini, LKS dalam dalam menggunakan akad ijarah dalam memaknai upah-mengupah dipahami sebagai LKS melaksnakan pekerjaan tertentu dari permintaan nasabah melalui pembayaran upah yang disebut dengan fee atau ujrah. Sehingga LKS memiliki fungsi sebagai musta'jir (orang yang menerima upah), sementara nasabah sebagai mu'ajjir (orang yang memberikan upah). Contohnya pada embiayaan pendidikan, dalam hal ini nasabah meminta LKS agar melaksanakan jasa pengurusan anaknya dalam memasuki bangku sekolah maupun kuliah. Sehingga, LKS wajib melaksankan pekerjaan pengurusan tersebut yakni berhak atas ujrah dari kerja dalam pengurusannya tersebut. Besaran upah (ujrah) wajib disepakati di awal serta dinyatakan dalam wujud nominal bukan dalam wujud persentase sesuasi dalam fatwa tentang pembiyaan dalam multijasa (Azizah, 2014).

Namun, Kelemahan pada akad tersebut yakni ada dalam kerja yang akan dilakukan oleh LKS yang dalam hal ini LKS memiliki kebanyakan kekurangan SDM tenaga dalam melaksankan pembayaran, kecuali bagi LKS yang telah melaksankan kerjasama maupun pihak ketiga membuka akses online. Kelemahan ini tidak bisa diatasi contohnya dalam melaksankan akad wakalah atau perwakilan pada nasabah kembali. Kasus seperti ini tidak dilarang secara fikih, sebab logika dari akad tersebut yakni nasabah datang ke LKS 
meminta lembaga keuangan dalam mengurusi urusannya dengan memberikan imbalan atau upah. Namun oleh lembaga keuangan pengurusan tersebut diwakilkan terhdadap nasabah kembali tanpa imbalan atas wakalah tersebut. Namun LKS yang menerima imbalan dari pekerjaan yang sebenarnya secara nyata tidak dilakukannya. Sehingga kasus ini mirip dengan jual beli inah yang tidak diperbolehkan oleh mayoritas para fuqaha sebab menjadi hilah agar memperoleh imbalan tanpa padanan yang dibetulkan secara syara yakni riba.

Sebab itu pembiayaan pada multijasa berlandaskan akad ijarah yang berarti upahmengupah dari jasa yang dilaksankan, mengharuskan pihak LKS secara nyata melaksankan pekerjaan jasa ini, maupun melimpahkan terhadap pihak lain selain nasabah, baik dari dasar akad wakalah maupun ijarah. Jika yang dipakai ialah akad wakalah, dalam hal ini LKS bisa mengambil perolehan dari margin antara ujrah yang berikan pada pihak ketiga yang melakukan kegiatan dalam kebutuhan nasabah ini dengan ujrah yang dapat diterima atas nasabah. Sementara jika yang dipakai ialah akad ijarah, namun berefek pada tingginya imbalan yang dipikul nasabah, sebab sebetulnya imbalan tersebut dibagi pada dua, yaitu bank serta pihak ketiga yang melaksanakannya. Tingginya upah yang ditanggung nasabah sehingga pembiayaan ini tidak kompetitif. Belum lagi tidak seluruh nasabah cocok melalui pihak ketiga tersebut. Sehingga pada kedua alternatif tersebut, hanya terbatas terhadap lembaga yang sudah menjalin kerjasama terhadap pihak LKS (Rizkia, n.d.).

Sementara jika produk pembiayaan multijasa ini memakai akad kafalah, maka seluruh yang ada kaitannya dengan hukum kafalah, baik dari sisi rukun, syarat maupun ketentuan lainnya seperti dalam pernyataan dalam fatwa DSN MUI mengenai pembiayaan Multijasa tersebut. Makna dari Kafalah dalam bahasa bermakna menjamin, sementara dalam terminologi fikih, para ahli memiliki perbedaan dalam memaknai kafalah. Ulama Malikiyyah, Shafi'iyyah serta Hanabilah memaknai kafalah yakni menggabungkan tanggungan penjamin kepada tanggungan orang yang dijamin dalam menetapi hak nya. Sementara ulama Hanafiyyah memakanai dari kafalah yakni menggabungkan tanggungan dari seseorang ke tanggungan orang lain pada tuntutan. Sehingga dalam fikih tersebut bisa disimpulkan bahwasanya secara umum kafalah merupakan akad pemberian jaminan yang diberikan oleh satu pihak terhadap pihak lain dimana pemberi jaminan bertanggung jawab atas dari pembayaran kembali suatu utang yang menjadi hak penerima jaminan (Firmansyah, 2016).

Sehingga makna dari kafalah tersebut di atas, bila pembiayaan multijasa memakai akad kafalah, sehingga LKS dalam hal ini memiliki fungsi sebagai penjamin ( $k a f i l$ ) saja. Dalam hal ini ketika nasabah meminta pembiayaan multijasa, nasabah diwajibkan belum memiliki tanggungan terhadap pihak lain. Sebab fungsi dari kafalah ialah sebagai penguat saja. Apabila kafalah ini atas inisiatif atau permohonan orang yang berutang sehingga ia bisa memiliki fungsi yakni: Sebagai penguat di hadapan calon pemberi piutang supaya percaya serta aman bertransaksi sebab adanya kafil yang menjamin terbayarnya utang; dan kafalah ini sebagai penguat atas diri pengutang sendiri untuk melaksankan transaksi yang menyebabkan utang sebab ada jaminan dari kafil. Jika terjadi sesuatu, akan ada dana talangan dari seorang kafil.

Sehingga demikian pembiayaan multijasa melalui akad kafalah kurang akomodatif serta kurang efisien baik waktu ataupun tenaga. Sebab dalam pembiayaan ini berlaku ketentuannya yakni:

a. Akad kafalah hanyalah sebagai akad penjaminan, sehingga ketika LKS melaksankan pembiayaan multijasa berdasarkan pada akad kafalah, semestinya ketika saat itu ia tidak dengan langsung memberikan dana talangan yang berbentuk qard (pinjaman tanpa bunga) terhadap nasabah. Jika LKS langsung memberikan qard ketika saat itu maka tidak berlaku akad kafalah, namun akad qard saja. 
b. Dana talangan dalam hal ini hanya bisa diberikan ketika nasabah tidak bisa membayar tanggungannya, ketika jatuh tempo, bukan saat akad kafalah. Inilah juga ada dalam pernyataan oleh Direktorat Perbankan Syariah Bank Indonesia pada buku Kodifikasi Produk Perbankan Syariah mengenai Pembiayaan Multijasa melalui akad kafalah di poin terakhir yakni berbunyi, "Dalam hal ini nasabah tidak bisa mencukupi kewajiban terhadap pihak ketiga, sehingga bank melaksankan pemenuhan keharusan nasabah terhadap pihak ketiga dengan memberi dana talangan sebagai pembiayaan atas dasar akad al-qard yang wajib diselesaikan oleh nasabah". Sehingga dana talangan itu konsekuensi dari akad kafalah, yang mana kafilil yakni penjamin/LKS bertanggungjawab terhadap kelancaran pembayaran utang nasabah terhadap pihak ketiga.

c. Sehingga meskipun dana talangan ialah konsekuensi dari kesediaan LKS menjadi kafil terhadap nasabah, akan tetapi tidak semua akad kafalah berbuntut kepada pemberian dana talangan. Talangan ini hanya bersifat kasuistik, yakni jika terjadi kasus nasabah tidak bisa melaksanakan pembayaran terhadap pihak ketiga sesuai perjanjian. Sehingga jika melaksankan pembiayaan multijasa berdasarkan pada akad kafalah, ia tidak wajib mengeluarkan dana talangan. Namun, realitasnya jika calon nasabah meminta pembiayaan multijasa, nasabah butuh uang serta berharap pulang dari bank dengan membawa uang agar dapat memenuhi kebutuhan dalam pembiayaannya.

d. Ujrah pada kafalah tidak bergantung terhadap pemberian dana talangan. LKS memberikan dana talangan ataupun tidak, nasabah tetap berkewajiban membayar ujrah kepada bank sebagai upah atas jasa kafalah (Nugraheni, 2017).

Sehingga dari pertimbangan beberapa poin di atas bisa disimpulkan bahwasanya pembiayaan multijasa berdasarkan pada akad kafalah sedikit sulit serta sedikit rumit untuk diterapkan. Mungkin dari pertimbangan ini LKS menyebabkan tidak menggunakan akad ini pada pembiayaan multijasa, melainkan memakai akad ijarah.

\section{Inovasi PenerapanAkad Hybrid Contract dalam Produk Multijasa}

Sebagaimana dijelaskan diatas bahwa akad ijarah dan kafalah masih dianggap rumit dalam operasionalnya dikarenakan masih menggunakan akad tunggal sehingga dalam pelaksanaannya bank kesulitan serta ada nasabah yang ingin melakukan belanjanya sendiri sesuai yang dibutuhkan. Sehingga dengan keterbatasan tersebut selanjutnya untuk mengakomodasi kebutuhan nasabah mencari barang sesuai keinginannya serta untuk mempermudah operasional LKS sehingga dibutuhkan akad wakalah (perwakilan) dari bank terhadap nasabah agar melaksakakan sewa atas barang terhadap pihak ketiga atas nama LKS. Begitu juga dalam akad-akad yang dipakai dalam multijasa memperhatikan rukun akad tersebut. Hybrid contract dalam hal ini menggabungkan akad ijarah dan wakalah. Akad ijarahnya sebagai akad dalam pembiayaan multijasa dan akad wakalah sebagai pemberian kuasa terhadap nasabah dalam melaksanakan pembiayaan yang diperlukan. Namun setiap LKS yang dalam hal bank syariah memiliki perbedaan dalam melayani produk pembiayaan multijasa sesuai dengan Menurut Fatwa DSN-MUI No.44/DSNMUI/VII/2004 mengenai pembiayaan multijasa, dijelaskan bahwa pembiayaan multijasa dapat dilaksanakan dengan dukungan dari para praktisi bank syariah sebagai wujud dari penerapan prinsip syariah (Firmansyah, 2016).

Adanya hybrid contract atau multi akad pada produk multijasa kurang pas. Sebab dalam hal ini pembiayaan mulijasa menurut fatwa DSN-MUI Fatwa DSN-MUI No.44/DSN-MUI/VII/2004 Tentang Pembiayaan Multijasa, dijelaskan bahwa penggunaan ijarah memberikan perolehan keuntungan berupa imbalan atau upah dari jasa yang diberikan, sementara bila ditambah dengan akad wakalah yang diwakilkan pada nasabah 
menghilangkan tanggungjawab atau kewajiban nasabah membayar upah dari produk multijasa tersebut. Dalam hal ini yang menjadi persoalan yakni bank mewakilkan kepada nasabah dalam melakukan pembiayaan, yang hal ini nasabah dimanfaatkan tenaganya tanpa memberikan jasa sesuai produknya yakni multijasa. Namun, ada klarifkasi dari pihak bank bahwa pembiayaan multijasa dengan menggabungkan akad ijarah dan wakalah memiliki tujuan yakni nasabah lebih tahu apa yang nasabah perlukan sebab itu bank mewakilkan pada nasabah.

Namun sebenarnya ada akad alternatif bagi pembiayaan multijasa ini akad hawalah bil ujrah selain yang telah difatwakan oleh DSN MUI di atas. Dalam alternatif ini ialah pembiayaan multijasa berdasarkan pada akad hawalah. Pembiayaan multijasa dengan memakai akad hawalah bisa lebih fleksibel, lebih mudah serta lebih sederhana bila dibandingkan dengan memakaii ijarah atau akad kafalah, sehingga bisa lebih kompetitif. Oleh karena itu melalui adanya alternatif ini pembiayaan multijasa secara umum bisa lebih fleksibel sebba ada beberapa pilihan akad yang cocok dengan kebutuhan nasabah yang kompetitif.

Hawalah ataupun hiwalah secara bahasa bermakna al-tahwil serta al-intiqal yang bermakna memindahkan dari suatu tempat ke tempat lain. Sementara secara terminologi fikih, para ahli memiliki perbedaan dalam menafsirkannya. Secara umum ahli fikih memaknainya yakni sebagai "pemindahan tanggungan (utang) dari tanggungan seseorang terhadap tanggungan orang lain”. Sehingga hawalah ialah pengalihan utang dari orang yang memiliki utang terhadap orang lain yang wajib menanggungnya. Hal ini terjadi perpindahan tanggungan maupun hak dari satu orang terhadap orang lain. Dalam istilah para ulama, hawalah merupakan pemindahan beban utang dari muhil yakni orang yang berutang menjadi tanggungan muh 'alaih yakni orang yang berkewajiban membayar utang tersebut (Jafar et al., 2013).

Pembiayaan multijasa dengan berdasar akad hawalah dapat melalui tiga alternatif. Alternatif pertama, menggunakan akad hawalah saja. Sementara yang menajdi alternatif kedua serta ketiga yakni dengan akad hibrid ('uqud murakkabah) maupun multi akad, yakni mejadi gabungan dua akad maupun lebih pada satu kesepakatan baru. Seluruh alternatif tersebut berpegang pada dibolehkannya utang ghayr lazim dalam akad hawalah sebagaimana pendapat madzhab Hambali. Bergabungnya dua akad dalam satu kesepakatan atau hybrid contract pada produk LKS kontemporer yakni diperbolehkan oleh mayoritas ahli fikih. Hybrid contract yang dilarang hanyalah wujud pengecualian dari keumuman kaidah mu'amalah yang berlandaskan kepada kebolehan seluruh akad kecuali yang dilarang oleh syara. Pendapat ini juga lebih sesuai dengan tujuan syara yakni maqashid syariah merupakan adanya kemudahan dalam melaksankan muamalah, keringanan dalam beban serta memberi peluang inovasi, serta lebih relevan dengan perkembangan zaman maupunkebutuhan manusia akan transaksi dan akad-akad modern yang lebih kompetitif.

Namun kebolehan multi akad tersebut wajib sesuai dengan Batasan-batasan serta koridor syariah, secara koridor syariah multiakad boleh asal tidak bermaksud untuk untuk mengambil riba dengan jalan ini berdasarkan qiyas dan illat. Multi akad yang menjadi alternative yang fleksibel dalam pembiayaan multijasa ini ialah akad hawalah bi al-ujrah (hawalah dengan imbalan) serta wakalah (perwakilan), yang dikumpulkan dalam satu kesepakatan (akad). Kedua akad tersebut dibolehkan oleh Fuqaha maupun ulama secara sendiri-sendiri dan juga telah ditetapkan fatwanya oleh DSN MUI: hawalah bi al-ujrah ditetapkan dalam fatwa No. 58/DSN-MUI/V/2007, sementara wakalah dikukuhkan pada fatwa No. 10/DSN-MUI/IV/2000. Begitu juga jika diukur dengan batasan-batasan kebolehan multi akad di atas, maka multi akad yang ialah gabungan dari akad haawalah bi al-ujrah dengan akad wakalah ini diperbolehkan. 


\section{Multijasa berdasarkan pada Akad hawalah menggunakan Hybrid Contract sebagai Alternatif Inovasi Pembiayaan yakni:}

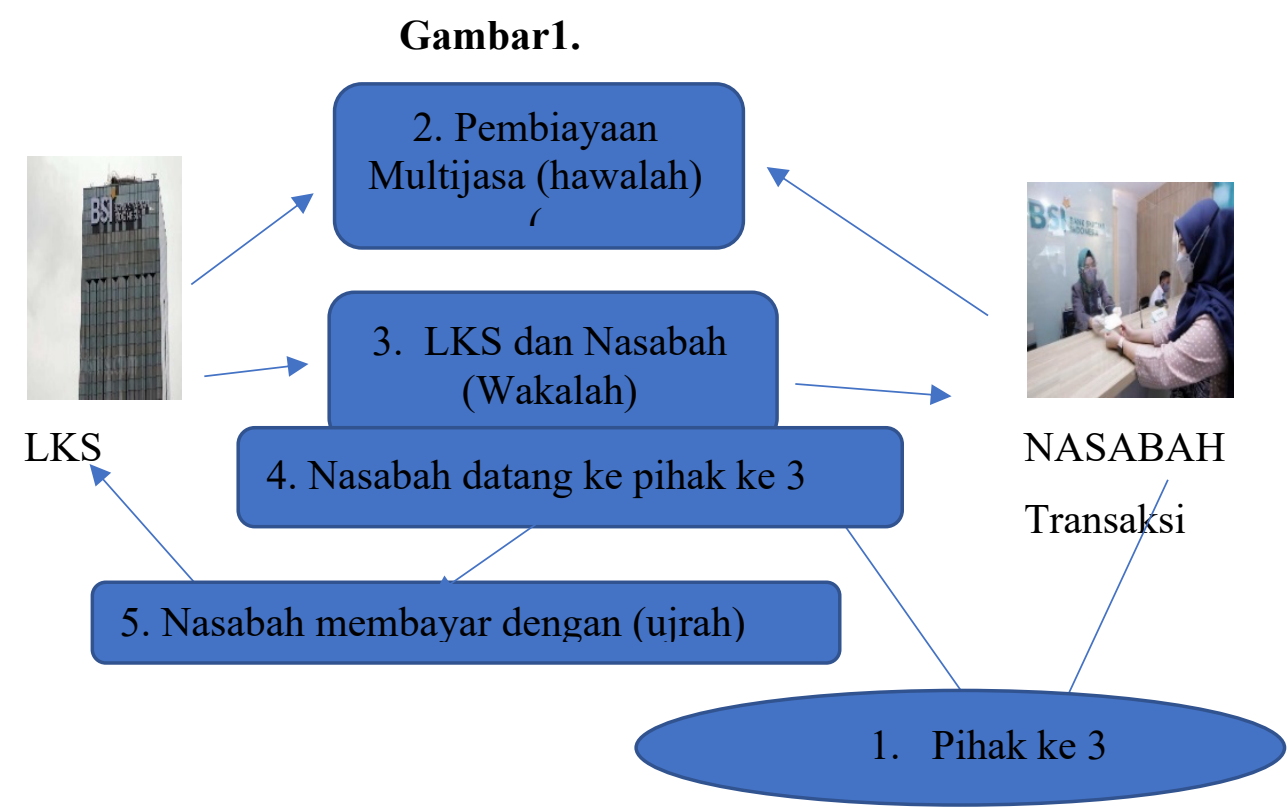

Gambar 1. Mekanisme Pembiayaan Multi Akad hawalah bi al-ujrah dengan wakalah Keterangan:

Alternatif pertama ini memakai multi akad, yakni menggabungkan antara hawalah bi al-ujrah dengan wakalah. Secara garis besar mekanisme dari pembiayaan multijasa IB dalam alternatif ini sebagai berikut:(Nizaruddin, 2013)

a) Nasabah melakukan transaksi dengan pihak ketiga sehingga menimbulkan tanggungan terhadapnya seperti pendaftaran sekolah anaknya, pesan makanan maupun jasa lainnya;

b) Nasabah datang ke LKS meminta pembiayaan multijasa IB berdasarkan akad hawalah dengan membawa bukti utang, seperti faktur tagihan, surat pemesanan atau lainnya dan persyaratan lainnya. Apabila permintaan nasabah tersebut disetujui dengan imbalan (ujrah) tertentu yang disepakati, sehingga para pihak (LKS serta nasabah) menandatangani pembiayaan multijasa dengan menggunakan akad hawalah bi al-ujrah;

c) Kemudian LKS membuat akad wakalah dengan nasabah supaya nasabah tersebut menjadi wakil dari LKS dalam membayarkan tanggungan nasabah yang di-hawalahkan terhadap LKS tersebut yang diikuti dengan penyerahan uang sejumlah tanggungan maupun utang nasabah yang menjadi objek hawalah dari LKS terhadap nasabah untuk dibayarkan terhadap pihak ketiga;

d) Selanjutnya nasabah datang pada pihak ketiga untuk melunasi utangnya atas nama LKS;

e) Nasabah membayar utangnya yang telah dialihkan ke LKS ditambah imbalan (ujrah) yang disepakati terhadap LKS secara angsuran dalam batas waktu yang disepakati bersama (Wahab, 2020).

Alternatif kedua menggunakan hybrid contract, berupa gabungan dari akad hawalah bi al-ujrah dengan akad wakalah. Secara garis besar mekanisme pembiayaan ini ialah sebagai berikut: 


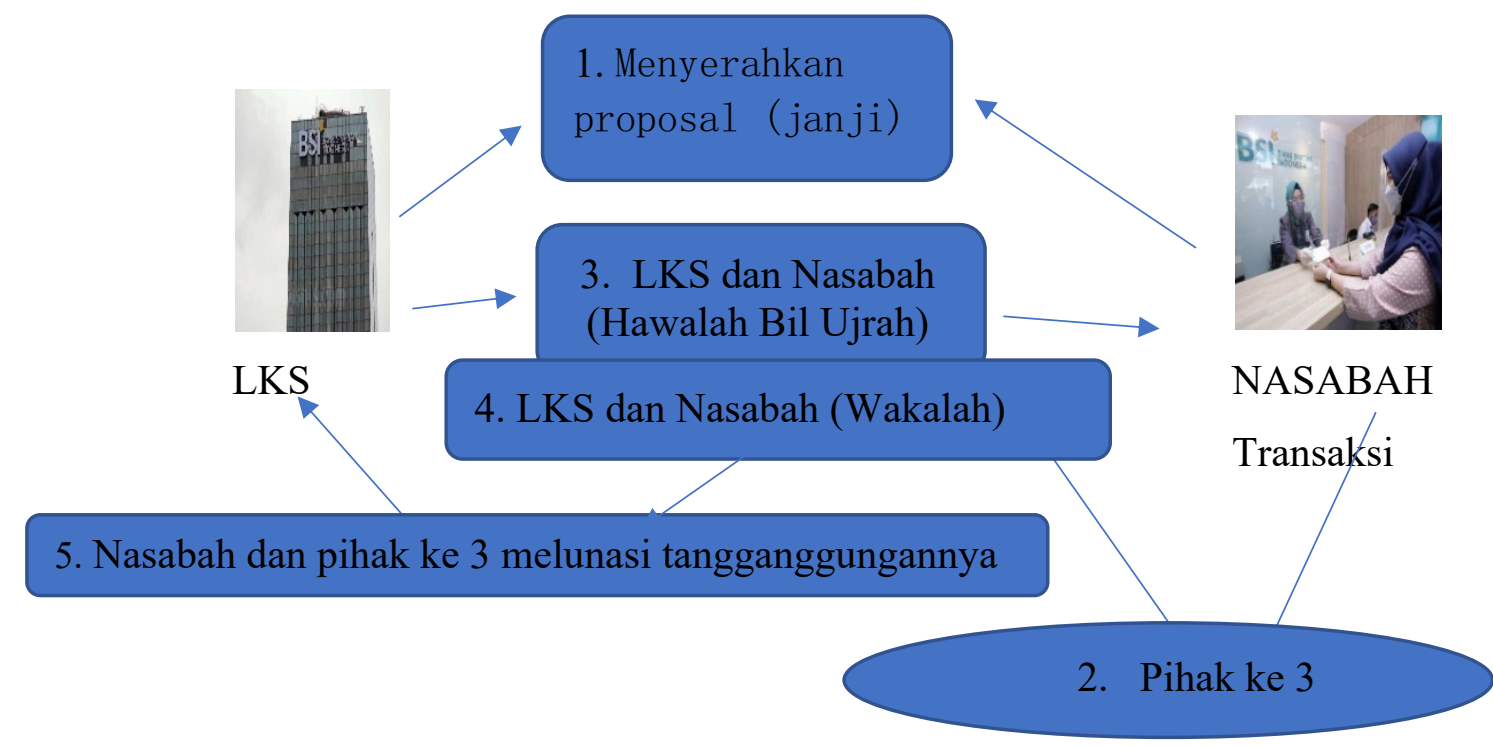

Gambar 2. Alternatif Pembiayaan dengan Akad Hawalah Bi Al-Ujrah dengan Akad Wakalah

Keterangan:

a) Nasabah yang memerlukan pembiayaan seperti untuk pernikahan, sekolah ataupun lainnya, datang ke LKS untuk negosiasi awal. Setelah melihat proposal pembiayaan, LKS berjanji (wa'd) untuk melaksankan hawalah atas utang nasabah saat nasabah telah melaksanakan transaksi yang menyebabkan tanggungan atau utang terhadap pihak lain.

b) Berpegang terhadap janji LKS tersebut, nasabah melakukan transaksi yang diinginkannya dengan pihak lain (pihak ketiga) yang nantinya menimbulkan tanggungan nasabah terhadap pihak ketiga tersebut.

c) Nasabah datang lagi ke LKS dengan membawa bukti utang dari pihak ketiga selanjutnya kedua belah pihak menandatangani akad hawalah bi al-ujrah.

d) Selanjutnya LKS membuat akad wakalah dengan nasabah agar nasabah tersebut menjadi wakil LKS dalam membayarkan tanggungan nasabah yang di-hawalahkan terhadap LKS tersebut yang kemudian diikuti dengan penyerahan uang sejumlah tanggungan maupun utang nasabah yang menjadi objek hawalah dari LKS terhadap nasabah untuk dibayarkan terhadap pihak ketiga;

e) Nasabah datang kepada pihak ketiga untuk melunasi tanggungannya atas nama LKS.

f) Nasabah membayar utangnya yang sudah dialihkan ke Lembaga Keuangan Syariah (LKS) ditambah dengan imbalan (ujrah) yang disepakati terhadap LKS secara angsuran.

Sehingga dapat disimpulkan bahwa inovasi dalam alternatif menggunakan hybrid contract pertama serta kedua diatas pihak LKS dengan pihak ketiga belum ada kerjasama. Alternatif pertama bagi nasabah yang sudah yakin jika proposal pembiayaannya akan diterima oleh pihak LKS. Sehingga berdasarkan keyakinan tersebut memiliki beberapa indicator yakni: pertama, dari segi finansial, yang mengajukan ialah nasabah yang bankable misalnya PNS serta lainnya; kedua, dari wujud pembiayaan, yang diminta tidak terlalu besar; ketiga, nasabah sudah dikenal baik kejujuran serta amanahnya oleh LKS (Maman et al., 2017). Sementara alternatif ketiga bisa dipakai bagi nasabah yang tidak terlalu yakin jika proposal pembiayaannya diterima oleh LKS, sehingga nasabah ini butuh kepastian dari LKS terlebih dahulu sebelum melakukan transaksi kepada pihak ketiga. 


\section{KESIMPULAN}

Berdasarkan pemaparan diatas pada hybrid contract atau akad ganda pada pembiayaan multijasa, berlandaskan pada prinsip syariah pembiayaan Al-Ijarah Multijasa. Al-Ijarah Multijasa merupakan bagian dari Pembiayaan Multijasa, fatwa Dewan Syariah Nasional No. 44/DSN-MUI/VIII/2004 menyatakan bahwasanya pembiayaan multijasa ini dapat memakai akad Ijarah maupun akad Kafalah. Namun jika memakai akad kafalah maka wajib sesuai dengan ketentuan pada fatwa kafalah. Begitu juga dalam ijarah harus mematuhi sesuai dengan fatwa ijarah. Dalam ijarah pada LKS misalnya bisa menyalurkan pelayanan jasa keuangan seperti dalam pembiayaan Pendidikan universitas, pembiayaan kesehatan, pembiayaan pernikahan, pembiayaan untuk membayar utang, pembiayaan dalam membayar pajak serta biaya sewa (rumah, kendaraan, alat-alat pertanian, alat-alat perlengkapan usaha maupun gedung). Namun dalam inovasi bank Syariah bisa menggunakan akad ijarah dan wakalah namun ini juga masih dianggat rumit dalam operasionalnya, sehingga yang paling fleksibel adalah menggunakan akad hawalah bil ujrah dan wakalah.

\section{DAFTAR PUSTAKA}

Annisa Eka Rahayu, N. N. (2020). Kontruksi Akad Ijrah pada Fatwa DSN MUI tentang Pembiayaan Multijasa. Paper Knowledge . Toward a Media History of Documents, 7(59), 12-26.

Asfiyah, I. (2015). Implementasi Produk Pembiayaan Multijasa PT. BPRS PNM Binama Semarang. UIN Walisongo.

Azizah, A. I. (2014). Analisis Penerapan Akuntansi Produk Pembiayaan Ijarah Multijasa Pada PT. BPRS Asri Madani Nusantara.

Firmansyah, M. (2016). Implementation of Contract Hybrid Concept in Multi Services Products (Aplication of the Warranty Bank Products/Kafalah in Syariah Banks). International Journal of Nusantara Islam, 4(2), 85-96. https://doi.org/10.15575/ijni.v4i2.1253

Hakim, A. A., \& Mubarok, J. (2017). Metodologi Studi Islam. Rosda.

Jafar, N., Bahar, B., \& Lusiana, S. (2013). Perlindungan Hukum Terhadap Bank Syariah Pada Akad Hiwalah. Syari'ah, 02(04), 1-16.

Maman, D., Maman Sudirman, S. H., M Kn, M. H., Thohir Luth, T. L., Safa'at, R., Safa'at, R., Fadli, M., \& Fadli, M. (2017). Jurnal: Akad Qardh and Accesoir in Sharia Banking Not Yet Based on Sharia Economic Principles Free of Riba (Usury). Journal of Law, Policy and Globalization, 64, 1-7.

Maulana, L. (2020). Penerapan Konsep Hybrid Contract Dalam Pembiayaan Rahn Di Pegadaian Syari'Ah. AKSY: Jurnal Ilmu Akuntansi Dan Bisnis Syariah, 2(1), 47-66. https://doi.org/10.15575/aksy.v2i1.7860

Mumtahaen, I. (n.d.). Penerapan Hybrid Contract pada Produk Giro. Jurnal Ilmu Akuntansi Dan Bisnis Syariah.

Nizaruddin. (2013). Hiwalah Dan Aplikasinya Dalam Lembaga Keuangan Syari'ah. Studia Islamika, 7(1), 326-365.

Nugraheni, D. B. (2015). Analisis Yuridis Multi Akad Dalam Pembiayaan Pengalihan. Mimbar Hukum, 27(2), 241-255.

Nugraheni, D. B. (2017). Analisis Fatwa Dew an Syariah Nasional Tent ang Wakalah, Haw alah, dan Kaf alah Dalam Kegiat an Jasa Perusahaan Pem biayaan Syariah. 2, 124-136.

Nurcholis Syamsudin. (2019). Permasalahan hukum Dalam Transaksi Multi Akad Pembiayaan Dan Pembuktianya Pada Bank Syariah. Jurnal Hukum, Volume 2(1), 44 
68.

Riyaldi, R., \& Choirunnisak. (2021). Pembiayaan Multi Jasa Menggunakan Akad Ijarah Di PT. Bank Pembiayaan Rakyat Syariah (BPRS) Al Falah Banyuasin. Jimpa, 1(1), 3948.

Rizkia, D. (n.d.). Aplikasi Produk Ijarah Pada Pembiayaan Multijasa Di Bmt UbasyadaCiputat.

Sugiyono. (2017). Metode Penelitian Penelitian Kuantitatif, Kualitatif dan R\&D. In Bandung: Alfabeta (pp. 286-288).

Wahab, A. (2020). Hybrid Contracts on Sharia Banking: Study on Home Ownership Financing Product by Musharakah Mutanaqishah. 436, 805-809. https://doi.org/10.2991/assehr.k.200529.170 